\title{
Intraspecific somatic hybridization of mango (Mangifera indica L.) through protoplast fusion
}

\author{
Ramezan Rezazadeh*, Dion K. Harrison and Richard R. Williams \\ The University of Queensland Gatton, School of Agriculture and Food Sciences, Gatton Qld 4343, Australia. *Current \\ address for corresponding author: Agricultural and Natural Resources Research Center, Tooloo street, Golshahr Blvd., \\ Bandar Abbas, Hormozgan, Iran, *E-mail: ramezan.rezazadeh@uqconnect.edu.au
}

\begin{abstract}
Somatic hybridization of mango via protoplast fusion was attempted at cultivar level. Enzymatically isolated protoplasts from leaves of greenhouse-grown seedlings of cvs. 'Tommy Atkins', 'Keitt' and 'Haden' and from proembryonic masses (PEMs) of cv. 'Kensington Pride' were used. Protoplasts were fused by polyethylene glycol (PEG), embedded in Ca-alginate beads and cultured in shallow liquid culture on shaker (30 rpm). After 4 weeks, Ca-alginate beads were depolymerized and released microcolonies of PEMs were plated onto the solid culture media. After two consecutive subcultures, fast growing large clumps of PEMs were picked up and cultured as PEMs line for analyses. Flow cytometry analysis of 242 PEMs lines revealed 41 tetraploid lines. DNA fingerprinting of the regenerated embryos from the tetraploid lines showed that only four lines were somatic hybrids, all resulting from 'Haden' + 'Kensington Pride' protoplast fusions. By contrast, the tetraploid lines from 'Keitt' + 'Kensington Pride' and 'Tommy Atkins' + 'Kensington Pride' were autotetraploids. Root-tip chromosome counts on resulting germinated cotyledonary embryos confirmed that somatic hybrid embryo lines had a chromosome number of $2 n=4 x=80$ compared to diploid parents $(2 n=2 x=40)$. Of 50 deflasked somatic-hybrid, in vitro plantlets with true leaves only 3 plantlets formed the healthy apical bud (meristem) in the soil and grew normally.
\end{abstract}

Key words: Flow cytometry, Haden, Keitt, Tommy Atkins, Kensington Pride, Mangifera indica L., PEG, PEMs, RAF, somatic embryo.

\section{Introduction}

Mango (Mangifera indica L.), native to Indo Burma region, is one of the most important fruit crops in the tropics and frost-free subtropics of the world. Today the major limitation facing the production of mango is the shortage of superior cultivars mainly because of difficulties experienced in conventional breeding of mango including the small number of seeds produced, the complex nature of flowers, excessive fruit drop, long juvenility, high level of heterozygosity and polyembryony in some cultivars (Iyer and Degani, 1998). Most of the current mango cultivars are results of selection from open-pollinated seedling populations (Litz, 2004). Protoplast fusion and somatic hybridization techniques provide the opportunity for bypassing the conventional breeding barriers through direct transfer of cytoplasmic and nuclear genome to plant cells. Somatic hybridization could facilitate the introduction of the desirable traits like tolerance to biotic and abiotic stresses from cultivars and wild species of mango into cultivars of mango rootstocks (Litz, 2004). Examples of progress in the field of plant protoplast are obtaining diseases-resistant species through somatic hybridization (Austin et al., 1985; Deng et al., 1995; Hansen and Earle, 1995) and successful transfer of cytoplasmic-controlled male sterility between Brassica species through cybridizaion (donor-receiver parent) (Walters et al., 1992).

Somatic hybrids have been produced in Citrus spp. (Fu et al., 2003; Grosser et al., 1992; Grosser et al., 2000; Guo et al., 2000; Khan and Grosser, 2004; Miranda et al., 1997), grapevine (Matt and Blaich, 2000), banana (Matsumoto et al., 2002), persimmon (Tamura et al., 1995) and Actinida spp. (Xiao et al., 2004).
Mango, is considered one of the most recalcitrant species to in vitro condition, and thus has lagged behind other fruit crops in using biotechnological methods based on single cell and protoplast culture. Assessing the capability of mango protoplasts for fusion and the potential of regenerants for undergoing genomic changes stands as starting points for exploiting the somatic hybridization. To date, plant regeneration from protoplasts of proembryonic masses (PEMs) of mango cv. Amrapali has been obtained (Ara et al., 2000). There is no report available describing somatic hybridization of mango and protoplast culture from PEMs of other cultivars of mango or leaf of any cultivar of mango. Efficient techniques for protoplast fusion, plant regeneration and evaluation of outcome are necessary for somatic hybridization. This paper describes an attempt towards the somatic hybridization of mango through fusion of PEMs and leaf protoplasts, regardless of focusing on any target genes, for three parental combinations at cultivar level: 'Tommy Atkins' + 'Kensington Pride', 'Keitt' + 'Kensington Pride' and 'Haden '+ 'Kensington Pride'.

\section{Materials and methods}

\section{Plant material}

Leaves: In the absence of efficient protocols for in vitro shoot culture of mango, protoplast isolation from leaves of greenhousegrown seedlings was followed. Seedlings of cvs. 'Haden', 'Tommy Atkins' and 'Keitt' were grown under shady and humid condition for two consecutive flushes. Partially expanded leaves ( 2 week-old flushes) were surface sterilized, the epidermis was bruised and mid ribs, visible veins, leaf margins and any necrotic 
areas were removed. Leaf shreds were cut into thin strips (0.2-0.5 $\mathrm{mm}$ ) with razor blades with minimal wounding.

PEMs: Embryogenic cultures were obtained from nucellus of immature fruits of cv. 'Kensington Pride' as described for mango by DeWald et al. (1989). Slow growing PEMs induced on nucellar tissues turned to fast growing suspension when proliferated in liquid culture and were able to produce about $3 \mathrm{~g}$ fresh PEMs per each subculture. To obtain high-quality PEMs free of black clumps, cultures were sequentially transferred to fresh media and grown in 2,4-D -free media for the last subculture. Suspension cultures were passed through a $250 \mu \mathrm{m}$ mesh and centrifuged at $50 \times \mathrm{g}$ to pellet small cell aggregates of PEMs.

Protoplast isolation: Digesting solutions were composed of cell and protoplast washing (CPW) salts (Frearson et al., 1973) containing mannitol (0.7 M: osmolarity of $1100 \mathrm{mmol} \mathrm{kg}^{-1}$ and 0.5 M: $800 \mathrm{mmol} \mathrm{kg}^{-1}$ for PEMs and leaves, respectively) and $1.5 \%$ cellulase R-10 (Yakult Honsha Co., Japan), $1.0 \%$ hemicelluase (Sigma), and 0.75\% (PEMs), 1.5\% (leaves) Macerozyme (Yakult Honsha Co., Japan). Digesting solutions were adjusted to $\mathrm{pH}$ 5.8 and filter sterilized with $0.22 \mu \mathrm{m}$ millipore (Millex®) filter. After $1 \mathrm{~h}$ pre-plasmolysis, one gram of leaf strips $(0.2-0.5 \mathrm{~mm})$ or drained PEMs pellet transferred to $10 \mathrm{~mL}$ enzyme mixture in a $250 \mathrm{~mL}$ Erlenmeyer flask. The mixtures were incubated in darkness at $27^{\circ} \mathrm{C}$ for $14 \mathrm{~h}$ (PEMs) and $16 \mathrm{~h}$ (leaves) on gyratory shaker at $45 \mathrm{rpm}$ (leaves) and $30 \mathrm{rpm}$ (PEMs). After completion of incubation, digested cells and tissues were sequentially passed through a $75 \mu \mathrm{m}$ sterile stainless steel sieve and $40 \mu \mathrm{m}$ nylon sieve. The filtrate was transferred to a $15 \mathrm{~mL}$ centrifuge Falcon tube and centrifuged at $100 \times \mathrm{g}$ for $5 \mathrm{~min}$. After discarding supernatant, protoplast pellets of each treatment were washed twice with media of the corresponding osmolarity. Protoplasts were purified through density gradient centrifugation by placing $2 \mathrm{~mL}$ of crude protoplast suspension in CPW-osmoticum on the top of $4 \mathrm{~mL}$ of sucrose pad (25\% for PEMs and $21 \%$ for leaf protoplasts). After centrifugation at $80 \times \mathrm{g}$ for $3 \mathrm{~min}$, protoplasts were collected by Pasteur pipette (from intermediate density) and resuspended in fresh culture medium. Protoplast yields of 15.22 $\times 10^{6}$ per gram fresh weight $\left(\mathrm{g} \mathrm{fw}^{-1}\right)(\sim 86 \%$ viability $)$ from PEMs and $8.68 \times 10^{6} \mathrm{~g} \mathrm{fw}^{-1}$ from leaves of greenhouse-grown seedlings ( $\sim 84 \%$ viability) were obtained.

Protoplast fusion: Protoplast fusion was attempted for three parental combinations viz., 'Tommy Atkins' (leaves) + 'Kensington Pride' (PEMs), 'Keitt' (leaves) + 'Kensington Pride' (PEMs) and 'Haden' (leaves) + 'Kensington Pride' (PEMs). Briefly, purified leaf protoplast suspension were gently mixed with PEMs protoplast suspensions (each at density of $6 \times 10^{5}$ protoplast per $\left.\mathrm{mL}\left(\mathrm{Pp} \mathrm{mL} \mathrm{L}^{-1}\right)\right)$ at a 2:1 ratio $(\mathrm{v} / \mathrm{v})$, then pelleted by centrifugation $(75 \times \mathrm{g})$ and resuspended in W5 solution $(154 \mathrm{mM}$ $\mathrm{NaCl}, 5 \mathrm{mM}$ glucose, $125 \mathrm{mM} \mathrm{CaCl}_{2} .2 \mathrm{H}_{2} \mathrm{O}$ and $5 \mathrm{mM} \mathrm{KCl}, \mathrm{pH}$ 5.6 (Medgyesy et al., 1980) at a ratio of 1:2. A single drop (100 $\mu \mathrm{L}$ ) of the suspension was placed in the bottom of a Petridish $(60 \times 15 \mathrm{~mm})$ for $20 \mathrm{~min}$ (protoplast settlement), then an equal volume of $40 \%$ Polyethylene glycol (PEG) $\left(40{ }^{\circ} \mathrm{C}, \mathrm{pH} 7\right)$ was gently added to the periphery of the drop and incubated at room temperature for $20 \mathrm{~min}$. The PEG solution was prepared by adding $7 \mathrm{~mL}$ of filter-sterilized complementary solution [( $0.6 \mathrm{M}$ glucose, $10 \mathrm{mM} \mathrm{CaCl}_{2} .2 \mathrm{H}_{2} \mathrm{O}, 0.7 \mathrm{mM} \mathrm{KH}_{2} \mathrm{PO}_{4}$ (Kao et al., 1975) pH 8.0) to a vial containing $5 \mathrm{~g}$ of preheated PEG HYBRI-MAX ${ }^{\circledR}, \mathrm{MW}$
3,000-3,700 (Sigma)]. After 15 min of incubation, the fluid over the top of each drop was gently removed by a pipette using $20 \mu \mathrm{L}$ tips and the remaining solution was eluted 3 times with $100 \mu \mathrm{L}$ of W10 solution. W10 (Menczel et al., 1981) was freshly prepared by mixing 9 parts of stock $\mathrm{A}\left(0.4 \mathrm{M}\right.$ glucose, $66 \mathrm{mM} \mathrm{CaCl}_{2}, 10 \%$ DMSO) with one part of stock $\mathrm{B}(0.3 \mathrm{M}$ glycine-NaOH buffer, $\mathrm{pH}$ 10.5) and filter sterilized. Glycine- $\mathrm{NaOH}$ buffer $(\mathrm{pH} 10.5)$ was prepared by mixing $25 \mathrm{~mL}$ of Stock 1 ( $0.2 \mathrm{M}$ glycine $)$ with $19.5 \mathrm{~mL}$ of stock $2(0.2 \mathrm{M} \mathrm{NaOH})$ in a final volume of $100 \mathrm{~mL}$ deionised distilled water. After 20 min, W10 solution was washed three times with protoplast culture media. A few drops of sterile water were placed on the corner of each Petri dish to prevent dehydration and crystallization of mixtures during different incubation courses.

Protoplast culture: After fusion, protoplasts were gently embedded in Ca-alginate beads at an initial plating density (IPD) of $2.5 \times 10^{4} \mathrm{Pp} \mathrm{mL}^{-1}$ and suspended in shallow liquid culture media containing $1 \mathrm{mg} \mathrm{L}^{-1} 2,4-\mathrm{D}$ and $3.5 \mathrm{mg} \mathrm{L}^{-1}$ Kinetin. The basic culture media consisted of B5 major salts (Gamborg et al., 1968) with $4 \mathrm{mM} \mathrm{CaCl}_{2}$ and without $\left(\mathrm{NH}_{4}\right)_{2} \mathrm{SO}_{4}, \mathrm{MS}$ minor salts (Murashige and Skoog, 1962) plus the following organic compounds based on a survey of previously used media, $20 \mathrm{mg} \mathrm{L}^{-1}$ thiamine- $\mathrm{HCl}, 10 \mathrm{mg} \mathrm{L}^{-1}$ pyridoxine, $2 \mathrm{mg} \mathrm{L}^{-1}$ nicotinic acid, $5 \mathrm{mg}$ $\mathrm{L}^{-1}$ pantothenic acid, $2 \%$ coconut water $(\mathrm{CW}), 30 \mathrm{mg} \mathrm{L}^{-1}$ ascorbic acid, $1.5 \mathrm{~g} \mathrm{~L}^{-1}$ L-glutamine, $100 \mathrm{mg} \mathrm{L}^{-1}$ myo-inositol, $500 \mathrm{mg} \mathrm{L}^{-1}$ proline, $30 \mathrm{~g} \mathrm{~L}^{-1}$ sucrose and mannitol at $0.7 \mathrm{M}$ as osmoticum. The $\mathrm{pH}$ of the media was adjusted to 5.8 and all media were filter sterilized. Sodium alginate (Sigma) was dissolved in osmoticum $(0.7 \mathrm{M}$ mannitol) at a concentration of $4 \%(\mathrm{w} / \mathrm{v})$ (twice the final concentration) by stirring for $4 \mathrm{~h}$ then filter sterilized. Protoplasts were resuspended at $5 \times 10^{4} \mathrm{Pp} \mathrm{mL}^{-1}$ (twice the desired IPD) in a calcium-free culture media then mixed with alginate solution by gently swirling the tubes. The final mixture was then dropped (40 $\mu \mathrm{L}$ droplet) into culture media minus Na-alginate and plus $50 \mathrm{mM}$ $\mathrm{CaCl}_{2}$. After $1 \mathrm{~h}$, the resulting solidified $\mathrm{Ca}$-alginate beads were washed twice with the culture media each time for 10 min and fifty beads were suspended in $3 \mathrm{~mL}$ of shallow layer of liquid culture and incubated in the dark at $25^{\circ} \mathrm{C}$ with shaking at $30 \mathrm{rpm}$. After $12 \mathrm{~h}$, the whole liquid phase in the culture media was replaced with fresh culture media in order to wash out the remaining PEG and phenolics. Dilution was carried out by replacing $15 \%$ of the solution phase with mannitol-free media. After 4 weeks in culture media, cell colonies were released following depolymerization of Ca-alginate beads in $20 \mathrm{mM}$ sodium citrate solution, according to Scheurich et al. (1980).

Resulting colonies were plated onto the same media composition but free of mannitol and enriched with $80 \mathrm{~g} \mathrm{~L}^{-1}$ sucrose and $20 \%$ filter-sterilized CW solidified with $0.22 \%$ Gelrite (Sigma). After two consecutive subcultures, fast growing and large clumps of PEMs were selected and transferred to PEMs proliferation medium consisted of B5 major salts without $\left(\mathrm{NH}_{4}\right)_{2} \mathrm{SO}_{4}$, plus MS minor salts and Fe-EDTA, $12 \mathrm{mg} \mathrm{L}^{-1}$ thiamine, $4 \mathrm{mg} \mathrm{L}^{-1}$ nicotinic acid, $10 \mathrm{mg} \mathrm{L}^{-1}$ pyridoxine, $4.5 \mathrm{mg} \mathrm{L}^{-1} \mathrm{~L}$-glutamine, $6 \%$ sucrose, 1 $\mathrm{mg} \mathrm{L}^{-1} 2$,4-D and $3.5 \mathrm{mg} \mathrm{L}^{-1}$ Kinetin solidified with $0.22 \%$ Gelrite. Cultures were transferred to fresh media every two weeks. A disruption in PEMs proliferation by exclusion of 2,4-D from the culture medium allowed proembryonic cells to develop into the single or aggregate globular embryos within 10 days. Conversion 
of globular embryos to the further stages of early heart-shaped and cotyledonary took place within 3 weeks. To obtain cotyledonary embryos, opaque early-heart-shaped embryos (2-5 mm length) were easily separated from PEMs cultures without wounding the radicle and placed on to fresh medium.

Radicle elongation and rooting of cotyledonary embryos were obtained in germination media containing half-strength B5 major salts without $\left(\mathrm{NH}_{4}\right)_{2} \mathrm{SO}_{4}$, full strength $\mathrm{MS}$ minor salts, and vitamins and organics as for proliferation stage, $2 \%$ filter sterilized CW, $4.5 \%$ sucrose, $500 \mathrm{mg} \mathrm{L}^{-1}$ activated charcoal, solidified with $2.5 \mathrm{~g} \mathrm{~L}^{-1}$ Gelrite. For shoot growth, rooted embryos from the same PEMs line were transferred to $30 \mathrm{~mL}$ shoot growth medium in 250-mL Erlenmeyer flasks and maintained on a gyratory shaker at $60 \mathrm{rpm}$. Germination media without activated charcoal and Gelrite was used as shoot growth media. Embryos in both germination and shoot growth media were maintained at light intensity of $80-100 \mu \mathrm{mol} \mathrm{m} \mathrm{m}^{-2} \mathrm{~s}^{-1}$ with $16 \mathrm{~h}$ light $/ 8 \mathrm{~h}$ darkness. For acclimatization, fifty in vitro plantlets with true leaves and roots were transplanted to the mixture of $80 \%$ coco peat and $20 \%$ perlite and kept at $25{ }^{\circ} \mathrm{C}$ under reduced light $(20 \%)$ and $80 \%$ RH for 6 weeks then transferred to shaded greenhouse with 60 to $70 \%$ RH.

Flow cytometry: Nuclei suspensions were prepared from 50 mg PEMs from cv. 'Kensington Pride', and $1 \mathrm{~cm}^{2}$ of young leaf tissues each from cvs. 'Keitt', 'Tommy Atkins' and 'Haden' as diploid controls, and two single mature embryos from each putative somatic hybrid line following the protocol described by Galbraith et al. (1983) with some modifications as follows. Tissues were separately chopped with a sharp razor blade in $1 \mathrm{~mL}$ of ice-cooled (filtered by $0.22 \mu \mathrm{m}$ Millipore) buffer containing 45 $\mathrm{mM} \mathrm{MgCl} 2,30 \mathrm{mM}$ sodium citrate, $20 \mathrm{mM}$ MOPS, $0.1 \%$ Triton $\mathrm{X}-100,20 \mathrm{mM} \beta$-mercaptoethanol, and 0.1\% PVP, pH 7.0. After incubation for $2 \mathrm{~min}$, suspensions were filtered through a $21 \mu \mathrm{m}$ nylon filter (Millipore) and treated with $50 \mu \mathrm{g} \mathrm{mL}^{-1} \mathrm{RNase}$ A for $1 \mathrm{~min}$, then stained with propidium iodide (PI) $\left(40 \mu \mathrm{g} \mathrm{mL}^{-1}\right)$. The relative fluorescence of total DNA was measured for at least 2000 nuclei with a flow cytometry BD Laser II Analyser (Becton Dickenson), equipped with an argon laser at wave length of 488 $\mathrm{nm}$. The ploidy level of each regenerated line was determined by the peak position relative to that of the diploid controls.

Chromosome counting: Somatic chromosome spreads were prepared from meristematic cells of fast growing root tips (elongated radicle tips) from germinating embryos. For each callus line, two root tips, approximately $5 \mathrm{~mm}$ long were studied. Chromosomes spreads and staining were performed using Feulgen technique according to the procedure described by Tamura et al. (1996) with some modifications as follows. Root tips were immersed in distilled water at $4{ }^{\circ} \mathrm{C}$ for at least 24 $\mathrm{h}$, fixed in acetic acid: methanol (1:1) for $1.5 \mathrm{~h}$ then hydrolysed with $5 \mathrm{~N} \mathrm{HCl}$ for $60 \mathrm{~min}$ at $20^{\circ} \mathrm{C}$ after removing the fixative. Root tips were washed with distilled water after each step. The root tips were stained with Feulgen solution at $4{ }^{\circ} \mathrm{C}$ for $45 \mathrm{~min}$ then trimmed and $0.5-1.0 \mathrm{~mm}$ of tip was placed on a microscope slide, covered with a drop of enzyme solution (4\% Cellulase R10, 1.5\% Macerozyme R-10, 1\% Hemicellulase (Sigma), 0.07 $\mathrm{M} \mathrm{KCl}, 7.5 \mathrm{mM} \mathrm{Na}_{2}$ EDTA (pH 4), $5 \mathrm{mM}$ MES buffer and 0.5 $\mathrm{M}$ mannitol) and incubated in a water bath at $37{ }^{\circ} \mathrm{C}$ for $90 \mathrm{~min}$. Chromosome counts were performed on 10 cells for each root tip at $1000 \times$ magnification under oil emersion using an Olympus (BH2) microscope.

DNA analysis: Total DNA was double extracted from the PEMs of 'Kensington Pride', leaves of 'Tommy Atkins', 'Keitt' and 'Haden' and single embryos of putative somatic hybrids following the CTAB (cetyl trimethylammonium bromide) method (Carroll et al., 1995) with minor modification. Approximately $100 \mathrm{mg}$ of plant tissue was ground in liquid nitrogen and mixed with 750 $\mu \mathrm{L}$ of preheated $\left(65^{\circ} \mathrm{C}\right)$ Nuclear Lysis Buffer $(2 \%(\mathrm{w} / \mathrm{v}) \mathrm{CTAB}$, $1 \%(\mathrm{w} / \mathrm{v})$ PVP (MW 10,000), 0.5\% (v/v) $\beta$-mercaptoethanol, $2 \mathrm{M} \mathrm{NaCl}, 0.05 \mathrm{M}$ EDTA pH 8.0, $100 \mathrm{mM}$ Tris-HCl pH 8.0 containing $0.6 \% \mathrm{Na}_{2} \mathrm{SO}_{3}$ and $150 \mu \mathrm{L}$ of preheated $5 \%$ sarkosyl). $\beta$-mercaptoethanol and $\mathrm{Na}_{2} \mathrm{SO}_{3}$ were added to the lysis buffer immediately before use. The homogenate was incubated at 65 ${ }^{\circ} \mathrm{C}$ for $1 \mathrm{~h}$ with gentle inversion for $15 \mathrm{~min}$, then extracted with $900 \mu \mathrm{L}$ phenol: chloroform: isoamyl alcohol (25:24:1) (SigmaAldrich). The homogenate was centrifuged at 13,000 rpm for 15 min and supernatant transferred to a new microcentrifuge tube. A second extraction then occurred, with $900 \mu \mathrm{L}$ of chloroform: isoamyl alcohol (24:1) and mixed by 50 times inversion. Samples were centrifuged for an extra $15 \mathrm{~min}$ at 13,000 rpm, then the supernatant was transferred to a new microcentrifuge tube and DNA was precipitated by adding $620 \mu \mathrm{L}$ of pre-cooled $\left(4{ }^{\circ} \mathrm{C}\right)$ Isopropanol $(85 \% \mathrm{v} / \mathrm{v})$ for $1 \mathrm{~h}$ at room temperature $(\mathrm{RT})$, then centrifuged for $5 \mathrm{~min}$ at $2000 \mathrm{rpm}$. The precipitate was washed 3 times with 70\% ethanol, dried at RT for 20-30 min and dissolved in $100 \mu \mathrm{L}$ of tris-EDTA (TE) buffer $(10 \mathrm{mM}$ Tris $\mathrm{pH} 8.0,0.1 \mathrm{M}$ EDTA $\mathrm{pH}$ 8.0), $\mathrm{pH}$ 8.0. DNA yield was approximately $5 \mu \mathrm{g}$ per $100 \mathrm{mg}$ of embryos, 5-10 $\mu \mathrm{g}$ per $100 \mathrm{mg}$ of ground leaves and 10-15 $\mu \mathrm{g}$ per ground PEMs.

PCR for Randomly Amplified DNA Fingerprinting (RAF) was conducted according to the procedure described by Waldron et al. (2002) with minor modifications. Each reaction $(10 \mu \mathrm{L})$ contained $1 \times$ PCR buffer $(10 \mathrm{mM}$ Tris $(\mathrm{pH} 8.0), 10 \mathrm{mM} \mathrm{KCl}$, $5.0 \mathrm{mM} \mathrm{MgCl}$ ), $0.5 \mu \mathrm{L}$ dimethyl sulfoxide (DMSO), $20 \mu \mathrm{M}$ of each dNTP (dATP, dTTP, dGTP, dCTP), 1.5 U AmpliTaq Stoffel Fragment DNA polymerase (Roche Diagnostics Australia, Castle Hill, NSW), $2.5 \mu \mathrm{Ci}$ of $\alpha$-labelled 33P-dATP (Amersham), $5.0 \mu \mathrm{M}$ oligonucleotide primer, 1x bovine serum albumin (BSA) (New England Biolabs Inc $($ ) and $10-15$ ng genomic DNA template. The following random primers were used: W-15 (5'-ACACCGGAAC3'), K-14 (5'-CCCGCTACAC-3'), K-09 (5'-CCCTACCGAC-3'), K-13 (5'-GGTTGTACCC-3'), B-16 (5'-TTTGCCCGGA-3') (Operon technologies Inc.). The thermocycling program consisted of a hot start at $85{ }^{\circ} \mathrm{C}$, then an initial denaturing step for $5 \mathrm{~min}$ at $94^{\circ} \mathrm{C}$; followed by 30 amplification cycles of $94{ }^{\circ} \mathrm{C}$ for $30 \mathrm{~s}$, $60 \mathrm{~s}$ each at $57,56,55,54,53{ }^{\circ} \mathrm{C}$ and a final extension step at 72 ${ }^{\circ} \mathrm{C}$ for $5 \mathrm{~min}$.

Each sample of radio-labelled PCR product was mixed with an equal volume of gel loading buffer $(98 \%(\mathrm{v} / \mathrm{v})$ formamide, $10 \mathrm{mM}$ EDTA pH 8.0, 0.05\% (w/v bromophenol blue, $0.05 \%$ $(\mathrm{w} / \mathrm{v})$ xylene cyanol ) and denatured at $94{ }^{\circ} \mathrm{C}$ for $3 \mathrm{~min}$, cooled on ice. Amplified products $(2 \mu \mathrm{L})$ were then separated on large, denaturing 4\% (v/v) polyacrylamide sequencing gels (Bio-Rad Sequi-Genl' GT sequencing Cell, $50 \times 35 \mathrm{~cm}$ ) containing $7.5 \mathrm{M}$ urea in $1 \times$ TBE buffer $(0.1 \mathrm{M}$ Tris, 0.1 Boric acid, $20 \mathrm{mM}$ EDTA $\mathrm{pH} 8.0$ ). Gels were subjected to electrophoresis in $1 \times \mathrm{TBE}$ buffer at $100 \mathrm{~W}$ for $135 \mathrm{~min}$ then transferred to filter paper (Whatman 
$3 \mathrm{MM}$ ), dried and exposed to X-ray film (Kodak Biomax-MR) overnight at RT.

\section{Results}

Workable yields of protoplasts were obtained from young leaves of cvs. 'Haden', 'Tommy Atkins' and 'Keitt' and nucellar-derived PEMs of cv. 'Kensington Pride' (Fig. 1 a, b, c, d). Up to $18 \%$ of binary fusion (two cells in fusion stage) (Fig. 1 e, f) was observed during early protoplast fusion. Fusion of more than two protoplasts was also observed. The highest number of PEMs was produced in combination of 'Haden' + 'Kensington Pride' (Table 1). Of the largest PEMs selected from two consecutive subcultures in solid culture media, 242 lines were able to proliferate as PEMs lines (Fig. 1 g, h) which resulted in embryogenesis (Fig.1 i, j), embryo maturation (Fig. 1 k), germination (Fig. 1 1, m) and in vitro plantlet regeneration (Fig. $1 \mathrm{n}$ ) within 3 months. Of 50 rooted plantlets transplanted to the soil only 3 plantlets produced apical bud, healthy meristem and acclimatized to greenhouse condition with normal growth (Fig. $1 \mathrm{o}, \mathrm{p}$ ).

Flow cytometry analysis of the resultant 242 PEMs lines regenerated from 3 parental combinations using diploid mango nuclei as a control, revealed 41 tetraploid embryo lines (Fig. 2 $\mathrm{a}, \mathrm{b})$ and the remaining lines resembled the same fluorescence intensity as either diploid controls. RAF profiles of 41 tetraploid lines detected four somatic hybrids among regenerated tetraploid lines of 'Haden' + 'Kensington Pride'. Of the primers used, K-14 (Fig. $2 \mathrm{c}$ ) and $\mathrm{W}-15$ produced the highest number of polymorphic markers for all cultivars. All parent specific polymorphic RAF markers of 'Kensington Pride' and 'Haden' were present in four somatic hybrids and no novel markers as a result of recombinations were detected. None of the tetraploid PEM lines in 'Kensington Pride' + 'Keitt' and 'Kensington Pride' + 'Tommy Atkins' were found to be authentic somatic hybrids. These autotetraploid lines exhibited the specific RAF markers of 'Kensington Pride'. This shows that they were not autotetraploid regenerated from homokaryons (fused protoplasts) of leaf protoplasts.

Root tip chromosome counting on elongated radicle (Fig. 1 1) revealed that diploid parents had a chromosome number of $2 n=2 x=40$ and further confirmed that the four somatic hybrids of 'Haden' +'Kensington Pride' had a chromosome number of $2 \mathrm{n}=4 \mathrm{x}=80$ which is also consistent with the flow cytometry data (Fig. 1 q, r).

\section{Discussion}

In this study, intraspecific somatic hybrids of mango in the form of in vitro plantlets and a few acclimatized plants could be obtained. Somatic hybrids at intraspecific level have been reported for persimmon (Diospyros kaki) (Tamura et al., 1995). The majority of plant somatic hybrids have been obtained through interspecific and intergeneric protoplast fusion. In comparison to other studies with the fusion frequency of 5-10\% (Hidaka and Omura, 1992; Ishikawa et al., 2003; Kao and Michayluk, 1974; Xiao et al., 2004) our result with $18 \%$ binary fusion was satisfactory.

Despite the relatively higher population of leaf protoplasts to PEMs protoplasts in fusion solution, only a small number of microcolonies resembled leaf protoplast-derived microcolonies. This may be due to less ability of leaf protoplasts for cell division than that of PEMs protoplasts and setting the culture condition based on the PEMs protoplast requirements. Non-regenerable parents have been used in several somatic hybridizations systems (Grosser and Gmitter, 1990; Kisaka et al., 1997; Matsumoto et al., 2002). This phenomenon could be exploited as a selection strategy in mango which could further reduce the homokaryons or unfused regenerants.

Protoplasts are commonly fused by electrical or PEG method. Electrical fusion has been reported as simple and more efficient in terms of plant regeneration (Assani et al., 2005; Hidaka and Omura, 1992). Despite cytotoxicity (Kao and Michayluk, 1974; Mercer and Schlegel, 1979) and protoplast loss during the washing stage, the PEG method is generally more efficient in fusion frequency (Assani et al., 2005; Hidaka and Omura, 1992). Furthermore, PEG fusion is very cost-effective, not labour intensive and has been successfully used for Citrus spp. (Guo et al., 2004; Khan and Grosser, 2004; Mendes-da Gloria, 2000), Moricandi arvensis + Brassica oleraceae (Ishikawa et al., 2003) and Solanum spp. (Trabelsi et al., 2005). Results of our preliminary experiment aimed at reducing cytotoxicity of PEG showed that PEG at $40 \%$ in the form of pre-autoclaved-waxy HYBRI-MAX $^{\circledR}$ (Sigma) produced less protoplast mortality $(47 \%$ viability after $24 \mathrm{~h}, 18 \%$ binary fusion) than ordinary PEG in the form of powder MW3350 (38\% viability after 24 h, 16.5\% binary fusion).

Using flow cytometry for single embryos reduced the amount of work for selection of tetraploids. It only required $10 \mathrm{~h}$ of work to screen 242 samples from single embryo. This method is fast, easy and could be used at the early stages of development for screening of large populations. However we confirmed the results by chromosome counting even at the early stages of embryo germination, i.e. radicle elongation. Chromosome counting on radicle tips of germinated embryos eliminates the need to regenerate whole plants and can save time in cytological studies at the very early stages.

PCR-based methods such as RAPD has been used for verification of interspecies (Collonnier et al., 2003; Mendes-da Gloria et al., 2000; Xiao et al., 2004) and intergeneric (Binsfeld and Schnabl, 2002; Guo and Deng, 1998;) somatic hybrids. Detection of extensive polymorphism in this study, up to 23 polymorphic markers between parent cultivars, suggests that RAF (a highly

Table 1. Number of microcallus, tetraploid and somatic hybrid PEMs line and somatic hybrid plants obtained following the protoplast fusion of mango at three parental combinations at cultivar level: 'Tommy Atkins' + 'Kensington Pride', 'Keitt' + 'Kensington Pride' and 'Haden'+ 'Kensington Pride'

\begin{tabular}{|c|c|c|c|c|c|c|}
\hline \multirow[t]{2}{*}{ Parental combination ('cultivar') } & \multirow[t]{2}{*}{ Fusion drop } & \multicolumn{2}{|c|}{ Micro callus obtained } & \multirow{2}{*}{$\begin{array}{l}\text { Tetraploid } \\
\text { PEMs line }\end{array}$} & \multicolumn{2}{|c|}{ Somatic hybrid } \\
\hline & & Subculture 1 & Subculture 2 & & PEMs line & Plant \\
\hline 'Kensington Pride'+ 'Haden' & 10 & 1500 & 138 & 27 & 4 & 3 \\
\hline 'Kensington Pride' + 'Tommy Atkins' & 10 & 1200 & 50 & 6 & 0 & 0 \\
\hline 'Kensington Pride' +' Keitt' & 10 & 1320 & 54 & 8 & 0 & 0 \\
\hline Total & 30 & 4020 & 242 & 41 & 4 & 3 \\
\hline
\end{tabular}


polymorphic PCR based DNA marker) analysis is an efficient tool for somatic hybrid verification between closely related genotypes, in particular intraspecific hybrids. In a similar study intraspecific somatic hybrids of persimmon were verified by PCR-based markers of RAPD (Tamura et al., 1995). Sensitivity of RAFs method for detection of differences between the closely related genotypes of sugarcane, soybean (Waldron et al., 2002), macadamia (Peace et al., 2003) and mangosteen (Ramage et al., 2004) have been reported. This result is the first report on the use of such a marker system for mango and it appears suitable for application to other areas involving phylogenetic studies. Somatic hybrid embryogenic lines were maintained in proliferation medium and resulting embryos with extended true leaves and lateral roots were recovered.

No diploid or tetraploid lines were tested for organelle inheritance pattern in this study so there is no warranty that the non-somatic hybrid tetraploid lines at this stage are 100\% autotetraploid of
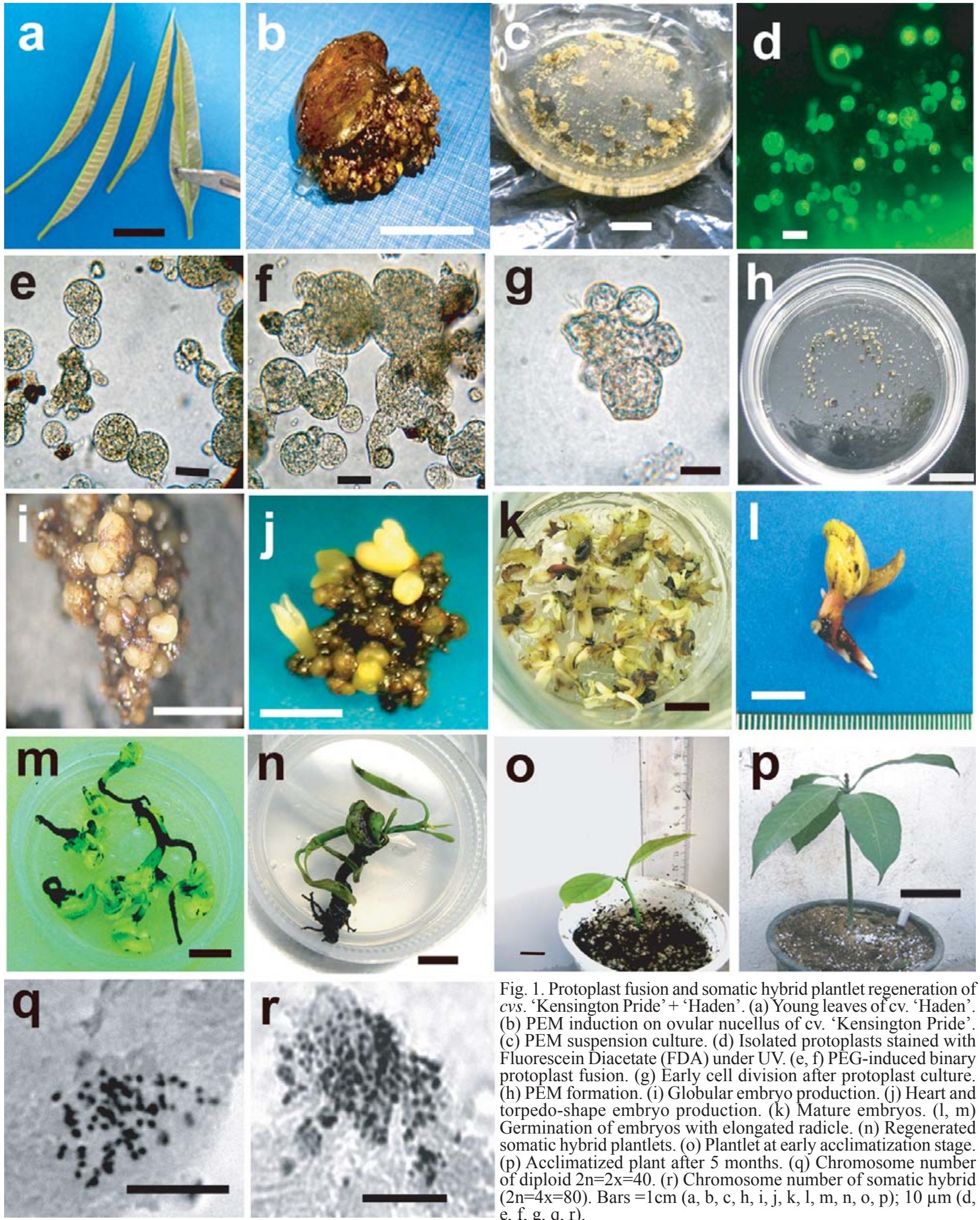

Fig. 1. Protoplast fusion and somatic hybrid plantlet regeneration of cys. 'Kensington Pride' + 'Haden'. (a) Young leaves of cv. 'Haden'. (b) PEM induction on ovular nucellus of cv. 'Kensington Pride'. (c) PEM suspension culture. (d) Isolated protoplasts stained with Fluorescein Diacetate (FDA) under UV. (e, f) PEG-induced binary protoplast fusion. (g) Early cell division after protoplast culture. (h) PEM formation. (i) Globular embryo production. (j) Heart and torpedo-shape embryo production. (k) Mature embryos. $(\mathrm{l}, \mathrm{m})$ Germination of embryos with elongated radicle. (n) Regenerated somatic hybrid plantlets. (o) Plantlet at early acclimatization stage. (p) Acclimatized plant after 5 months. (q) Chromosome number of diploid $2 \mathrm{n}=2 \mathrm{x}=40$. (r) Chromosome number of somatic hybrid $(2 \mathrm{n}=4 \mathrm{x}=80)$. Bars $=1 \mathrm{~cm}(\mathrm{a}, \mathrm{b}, \mathrm{c}, \mathrm{h}, \mathrm{i}, \mathrm{j}, \mathrm{k}, \mathrm{l}, \mathrm{m}, \mathrm{n}, \mathrm{o}, \mathrm{p}) ; 10 \mu \mathrm{m}(\mathrm{d}$, $e, f, g, q, r)$. 


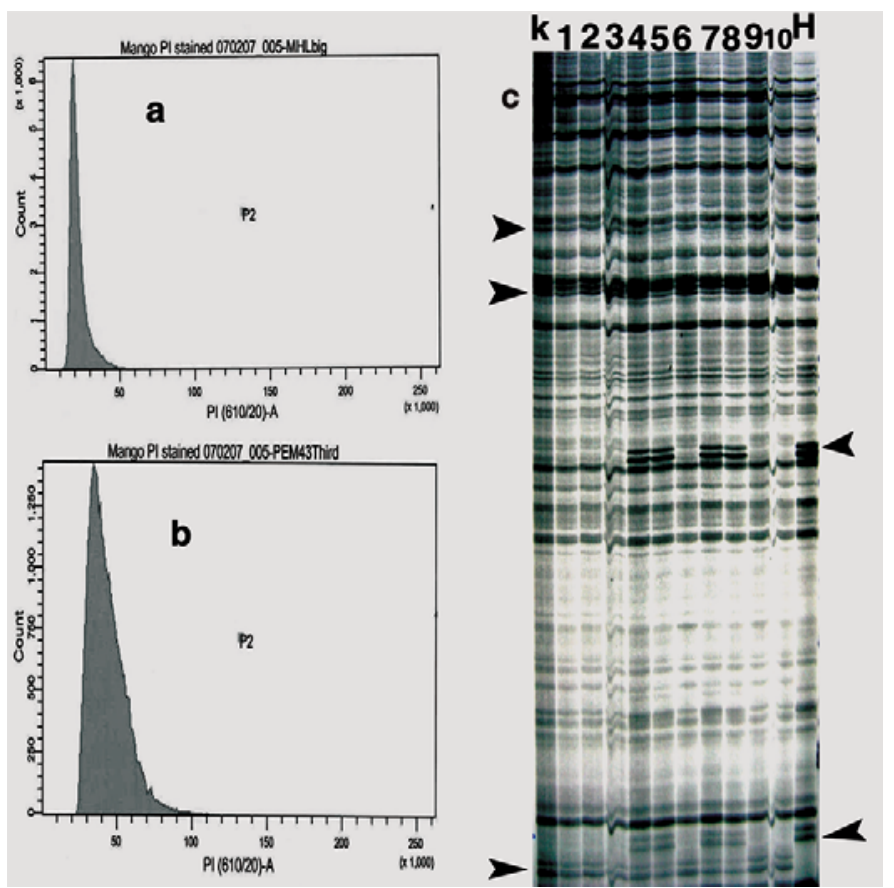

Fig. 2. Cytological and molecular analyses of fusion parents and regenerants. (a) Histograms of fluorescence intensities (arbitrary units) of leaf nuclei from diploid mango cv. 'Haden' (Mean=22). (b) Nuclei from tetraploid regenerants after protoplast fusion $(M e a n=43.4)$. (c) Partial RAF profile of K: 'Kensington Pride'; H: 'Haden', homokaryon tetraploid: 1, 2, 3, 6, 9, 10, and somatic hybrids ('Kensington Pride' + 'Haden'): 4, 5, 7, 8.

cv. 'Kensington Pride'. They may receive organelles from other parents which might not be detectable through the RAF markers we used.

However most of deflasked plantlets survived in the stunted form in the acclimatization process but a few of them produced apical bud and grew normally. Despite a satisfactory proliferation of proembryonic masses of mango, resulting somatic embryos showed abnormalities like having more than two cotyledons or no cotyledon with tubular cotyledon or secondary embryogenesis. These abnormalities are true in the case of nucellar somatic embryogenesis of almost all cultivars of mango. Further investigation is needed to improve embryogenesis in mango cultivars particularly the conversion rate and plant survival (Litz, 2004).

This study is the first to obtain intraspecific somatic hybrids of mango. Findings of our study in production of somatic hybrids open the ways for genetic improvement of mango through production of cybrids, auto- and allotetraploid $(2 n=4 x=80)$, haploid plants through haploidization $(n=2 x=40)$ and verification of other intraspecific and interspecific combinations. The fact that a small number of heterokaryon tetraploids were obtained indicates the low efficiency of the method used. Using nucleus or cytoplasmic inactivation techniques, flow cytometric cell sorting and parent harbouring marker genes such as GFP are recommended for further studies. This study has also laid the grounds for future research to identify organelle inheritance patterns and changes in chromosome arrangement resulting from protoplast fusion. Production of auto- and allopolyploid mango is found possible in this study which could facilitate the study of polyploidization in terms of field performances. A few somatic hybrid plantlets derived from PEMs lines grew normally following the deflasking and high percentage of them failed to produce healthy apical bud and remained stunted without further growth.

\section{Acknowledgement}

We thank Ross Bourne for assistance in tissue culture lab and Geoffrey Osborne and Virginia Nink at the Queensland Brain Institute for technical assistance in flow cytometry analysis.

\section{References}

Ara, H., U. Jaiswal and V.S. Jaiswal, 2000. Plant regeneration from protoplast of mango (Mangifera indica L.) through somatic embryogenesis. Plant Cell Rept., 19: 622-627.

Assani, A., D. Chabane, R. Haicour, F. Bakry, G. Wenzel and B. ForoughiWehr, 2005. Protoplast fusion in banana (Musa spp.): Comparison of chemical (PEG: polyethylene glycol) and electrical procedure. Plant Cell Tiss. Organ Cult., 83: 145-151.

Austin, S., M.A. Bear and J.P. Helegson, 1985. Transfer of resistance to potato leaf roll virus from Solanum brevidense into Solanum tuberosum. Plant Sci., 39: 75-82.

Binsfeld, P.C. and H. Schnabl, 2002. Molecular and cytogenetic constitution of plants obtained via two different somatic hybridization methods. Plant Cell Rep., 21: 58-62.

Carroll, B.J., V. Klimyuk, C.M. Thomas, G.J. Bishop, K. Harrison, S.R. Scofield and J.C.D. Jones, 1995. Germinal transposition of the maize element dissociation from T-DNA loci in tomato. Genetics, 139: 407-420.

Collonnier, C., I. Fock, I. Mariska, A. Servaes, F. Vedel, S. SiljakYakovlev, V. Souvannavong and D. Sihachakr, 2003. GISH confirmation of somatic hybrids between Solanum melongena and $S$. torvum: assessment of resistance to both fungal and bacterial wilts. Plant Physiol. Biochem., 41: 459-470.

Deng, Z.N., A. Gentile, F. Domina, E. Nicolosi and E. Tribulato, 1995. Selecting lemon protoplasts for insensitivity to Phoma tracheiphila toxin and regenerating tolerant plants. J. Amer. Soc. Hort. Sci., 120: 902-905.

DeWald, S.G., R.E. Litz and G.A. Moore, 1989. Optimizing somatic embryo production in mango. J. Amer. Soc. Hort. Sci., 114: 712716.

Frearson, E.M., J.B. Power and E.C. Cocking, 1973. Isolation, culture and regeneration of petunia leaf protoplasts. Dev. Biol., 33: 130-137.

Fu, C.H., W.W. Guo, J.H. Liu and X.X. Deng, 2003. Regeneration of Citrus sinensis (+) Clausena lansium intergeneric triploid and tetraploid somatic hybrids and their identification by molecular markers. In vitro Cell Dev. Biol. Plant, 39: 360-364.

Galbraith, D.W., K.R. Harkins, J.M. Maddox, N.M. Ayres, D.P. Sharma and E. Firoozabady, 1983. Rapid flow cytometry analysis of cellcycle in intact plant-tissues. Science, 220: 1049-1052.

Gamborg, O.L., R.A. Miller and K. Ojima, 1968. Nutrient requirement of suspension culture of soybean root cell. Expt. Cell Res., 50: 151-158.

Grosser, J.W. and F.G. Gmitter, Jr., 1990. Production fusion and citrus improvement. Plant Breeding Rev., 8: 339-374.

Grosser, J.W., F.G. Gmitter, Jr., F. Sesto, X.X. Deng and J.L. Chandler, 1992. Six new somatic citrus hybrids and their potential for cultivar improvement. J. Amer. Soc. Hort. Sci., 117: 169-173.

Grosser, J.W., P. Ollitrault and O. Oivares-Fuster, 2000. Somatic hybridization in citrus: An effective tool to facilitate variety improvement. In vitro Cell Dev. Boil. Plant, 36: 434-449.

Guo, W.W. and X.X. Deng, 1998. Somatic hybrid plantlet regeneration between Citrus and its wild relative, Murraya paniculate via protoplast electrofusion. Plant Cell Rept., 18: 297-300.

Guo, W.W., X.X. Deng and H.L. Yi, 2000. Somatic hybrid between navel orange (Citrus sinensis) and grapefruit (C. paradise) for seedless triploid breeding. Euphytica, 116: 281-285. 
Guo, W.W., D. Prasad, Y.J. Cheng, P. Serrano, X.X. Deng and J.W. Grosser, 2004. Targeted cybridization in citrus: transfer of Satsuma cytoplasm to seedy cultivars for potential seedlessness. Plant Cell Rept., 22: 752-758.

Hansen, L.N. and E.D. Earle, 1995. Transfer of resistance to Xanthomonas campestris pv campestris into Brassica oleracea L. by protoplast fusion. Theor. Appl. Genet., 91: 1293-1300.

Hidaka, T. and M. Omura, 1992. Regeneration of somatic hybrid plants obtained by electrical fusion between Satsuma mandarine (Citrusunshu) and rough Lemon (C. jambhiri) or Yuzu (C. junos). Jpn. J. Breeding, 42: 79-89.

Ishikawa, S., S.W. Bang, Y. Kaneko and Y. Matsuzawa, 2003. Production and characterization of intergeneric somatic hybrids between Moricandia arvensis and Brassica oleracea. Plant Breeding, 122: 233-238.

Iyer, C.A. and C. Degani, 1998. Classical breeding and genetics. In: The Mango-Botany, Production and Uses. R.E. Litz (ed), CAB International, Wallingford, pp. 49-68.

Kao, K.N., F. Constabel, M.R. Michayluk and O.L. Gamborge, 1975. Plant protoplast fusion and growth of intergeneric hybrid cells. Planta, 120: 215-277.

Kao, K.N. and M.R. Michayluk, 1974. Method for high-frequency intergeneric fusion of plant protoplasts. Planta, 115: 105-110.

Khan, I.A. and J.W. Grosser, 2004. Regenartion and characterization of somatic hybrid plants of Citrus sinensis (sweet orange) and Citrus micrantha, a progenitor species of lime. Euphytica, 137: 271-278.

Kisaka, H., M. Kisaka, A. Kanno and T. Kameya, 1997. Production and analysis of plants that are somatic hybrids of barley (Hordeum vulgaris L.) and carrot (Daccus carota L.). Theor. Appl. Genet., 94: 221-226.

Litz, R.E., 2004. Biotechnology and mango improvement. Acta Hort., 645: 85-92

Matsumoto, K., A.D. Vilarinhos and S. Oka, 2002. Somatic hybridization by electrofusion of banana protoplasts. Euphytica, 125: 317-324.

Matt, A. and R. Blaich, 2000. Somatic hybridization of grapevine protoplasts. Acta Hort., 528: 411-414.

Menczel, L., F. Nagy, Z. Kiss and P. Maliga, 1981. Streptomycin resistant and sensitive somatic hybrids of Nicotiana tabacum + Nicotiana knightiana-correlation of resistance to $N$. tabacum plastids. Theor. Appl. Genet., 59: 191-195.

Mendes-da Gloria, F.J., F.D. Mourao, L.E.A. Camargo and B.M.J. Mendes, 2000. Caipira sweet orange plus Rangpur lime: a somatic hybrid with potential for use as rootstock in the Brazilian citrus industry. Genet. Mol. Biol., 23: 661-665.
Medgyesy, P., L. Menczel and P. Maliga, 1980. The use of cytoplasmic streptomycin resistance-chloroplast transfer from Nicotiana tabacum into Nicotiana sylvestris, and isolation of their somatic hybrid. Mol. Gen. Genet., 179: 693-698.

Mercer, W.E. and R.A. Schlegel, 1979. Phytohemagglutinin enhancement of cell-fusion reduces polyethylene-glycol cytotoxicity. Expt. Cell Res., 120: 417-421.

Miranda, M., T. Motomura, F. Ikeda, T. Ohgawara, W. Saito, T. Endo, M. Omura and T. Moriguchi, 1997. Somatic hybrids obtained by fusion between Poncirus trifoliata (2x) and Fortunella hindsi (4x) protoplasts. Plant Cell Rept., 16: 401-405.

Murashige, T. and F. Skoog, 1962. A revised medium for rapid growth and bio assays with tobacco tissue cultures. Physiol. Plant, 15: 473-479.

Peace, C.P., V. Vithanage, C.G.N. Turnbull and B.J. Carroll, 2003. A genetic map of macadamia based on randomly amplified DNA fingerprinting (RAF) markers. Euphytica, 134: 17-26.

Ramage, C.M., L. Sando, C.P. Peace, B.J. Carroll and R.A. Drew, 2004. Genetic diversity revealed in the apomictic fruit species Carcinia mangostana L. (mangosteen). Euphytica, 136: 1-10.

Scheurich, P., H. Schnabl, U. Zimmermann and J. Klein, 1980. Immobilization and mechanical support of individual protoplasts. Biochimica Et Biophysica Acta, 598: 645-651.

Tamura, M., R. Tao and A. Sugiura, 1995. Regeneration of Somatic hybrids from electrofused protoplasts of Japanese persimmon (Diospyros kaki L.). Plant Sci., 108: 101-107.

Tamura, M., R. Tao and A. Sugiura, 1996. Production of dodecaploid plants of Japanese persimmon (Diospyros kaki L.) by colchicine treatments of protoplasts. Plant Cell Rept., 15: 470-473.

Trabelsi, S., R. Gargouri-Bouzid, F. Vedel, A. Nato, L. Lakhoua and N. Drira, 2005. Somatic hybrids between potato Solanum tuberosum and wild species Solanum vernei exhibit a recombination in the plastome. Plant Cell Tiss. Organ Cult., 83: 1-11.

Waldron, J., C. Peace, I. Searl, A. Furtado, N. Wade, M. Graham and B.J. Carroll, 2002. Randomly Amplified DNA Fingerprinting (RAF): A culmination of DNA marker technologies based on arbitrary-primed PCR amplification. J. Biomed. Biotechnol., 2: 141-150.

Walters, T.W., M.A. Mutschler and E.D. Earle, 1992. Protoplast fusion derived ogura male sterile cauliflower with cold tolerance. Plant Cell Rept., 10: 624-628.

Xiao, Z. A., L. Wan and B.W. Han, 2004. An interspecific somatic hybrid between Actinida chinensis and Actinida kolomikta and its chilling tolerance. Plant Cell Tiss. Organ Cult., 79: 299-306.

Received: February, 2011; Revised: July, 2011; Accepted: September, 2011 